PNL-SA-24002

\title{
FIELD TEST OF SIX-PHASE SOIL HEATING AT THE SAVANNAH RIVER SITE
}
P. A. Gauglitz
R. Schalla
J. S. Roberts
M. H. Schlender
T. M. Bergsman
T. R. Jarosh ${ }^{(a)}$
S. M. Caley
C. A. Eddy-Dilek ${ }^{(2)}$
W. O. Heath
B. B. Looney ${ }^{(a)}$
M. C. Miller
R. W. Ross

November 1994

Presented at the

Thirty-Third Hanford Symposium on Health and the

Environment Conference

November 7-11, 1994

Richland, Washington

Prepared for

the U.S. Department of Energy

under Contract DE-AC06-76RLO 1830

\section{Pacific Northwest Laboratory}

Richland, Washington 99352

\section{DISCLAIMER}

This report was prepared as an account of work sponsored by an agency of the United States Government. Neither the United States Government nor any agency thereof, nor any of their employees, makes any warranty, express or implied, or assumes any legal liability or responsibility for the accuracy, completeness, or usefulness of any information, apparatus, product, or process disclosed, or represents that its use would not infringe privately owned rights. Reference herein to any specific commercial product, process, or service by trade name, trademark, manufacturer, or otherwise does not necessarily constitute or imply its endorsement, recommendation, or favoring by the United States Government or any agency thereof. The views and opinions of authors expressed herein do not necessarily state or reflect those of the United States Government or any agency thereof. 


\section{DISCLAIMER}

Portions of this document may be illegible in electronic image products. Images are produced from the best available original document. 


\section{ABSTRACT}

Six-Phase Soil Heating (SPSH) was demonstrated as a viable technology for heating low permeability soils containing volatile organic contaminants as part of the Volatile Organic Compounds in Non-Arid Soils Integrated Demonstration (VOC Non-Arid ID) at the Savannah River Site. The soil at the integrated demonstration site is contaminated with perchloroethylene (PCE) and trichloroethylene (TCE); the highest soil contamination occurs in clay rich zones that are ineffectively treated by conventional soil vapor extraction due to the very low permeability of the clay. The SPSH demonstration sought to heat the clay zone and enhance the performance of conventional soil vapor extraction. Thermocouples at 30 locations quantified the areal and vertical heating within the treated zone. Results show successful heating of the targeted clay zone that contained the higher levels of soil contamination. The clay-zone temperatures increased to $100^{\circ} \mathrm{C}$ after 8 days of heating and were maintained near $100^{\circ} \mathrm{C}$ for 17 days. Electrical heating removed $17,000 \mathrm{gal}$ of water from the soil as steam, with peak removal rate of $1,500 \mathrm{gpd}$ of condensed steam.

After the initial start-up, electrical power was applied to the pattern at an average rate of $200 \mathrm{~kW}$. The total energy applied to the soil was $100,000 \mathrm{kWh}$. The volume of soil heated to above $70^{\circ} \mathrm{C}$ is estimated to be $1100 \mathrm{~m}^{3}$ giving an energy input of $90 \mathrm{kWh} / \mathrm{m}^{3}\left(70 \mathrm{kWh} / \mathrm{yd}^{3}\right)$. The average voltage (line to neutral) applied to the soil was $1000 \mathrm{~V}$. The voltages began at $250 \mathrm{~V}(\mathrm{~L}-\mathrm{N})$ during start-up and increased to $2400 \mathrm{~V}(\mathrm{~L}-\mathrm{N})$ at the end of the test. To quantify removal of PCE 
and TCE from the soil and soil drying, soil samples were taken (essentially every foot/ from six wells prior to heating and adjacent to these wells after heating; analysis of these samples is ongoing. 


\section{INTRODUCTION}

The Savannah River Site (SRS) is a 300-square-mile facility owned by the U.S. Department of Energy (DOE) and currently operated by Westinghouse Savannah River Company (WSRC). The Volatile Organic Compounds in Non-Arid Soils Integrated Demonstration (VOC Non-Arid ID) is being conducted near the MArea operations at SRS, along a corridor that once contained a process sewer leading to the M-Area seepage basin. In the early 1980s, this sewer line was discovered to be leaking process wastes into the subsurface and contributing to groundwater contamination in the vicinity of M-Area seepage basin. Although use of the sewer line has been discontinued, the slow release of chlorinated solvents such as trichloroethylene (TCE) and perchloroethylene (PCE) from the heterogeneous vadose zone soil continues to be a source of potential groundwater contamination.

Several candidate technologies currently exist, or are under development, to facilitate the removal of volatile contaminants from M-Area soil. Soil vapor extraction (SVE) is one of the more promising in situ technologies for removing volatile organic compounds like TCE or PCE from the subsurface. This technology succeeds when soil contaminants transfer readily into air that flows easily through the soil pore spaces. The contaminant is carried by the air through the soil to a

Pacific Northwest Laboratory is operated for the United States Department of Energy by Battelle Memorial Institute under contract DE-AC06-76RLO 1830. 
vacuum vent and removed. Successful venting requires that the contaminant be at least semi-volatile and the soil be permeable to the flow of air. In homogeneous and permeable soils, SVE produces rapid results with a relatively low overall cost. Conventional SVE, however, becomes infeasible when remediating low permeability non-homogeneous soils, or when semi-volatile contaminants are present (EPA/540/2-91/019A, 1991; Pedersen and Curtis, 1991).

A significant portion of the VOCs at the integrated demonstration site are retained in low permeability clay zones. A 10 -ft-thick clay zone beginning $30 \mathrm{ft}$ from the surface is the shallowest example (Eddy et al., 1991). Previous studies have shown that the rate of conventional SVE remediation of the Savannah River Site clays is quite slow; this is attributed to mass transfer limitations (Looney et al., 1991a, 1991b; Eddy-Dilek et al., 1993).

Soil heating can extend the effectiveness of SVE to less volatile compounds, to less permeable soils (like clays), and, potentially, to contaminant depths near or in the water table. All soil-heating processes increase the temperature of the soil and contaminant, causing an increase in the contaminant's vapor pressure and its removal rate. However, compared to heating by steam or hot air injection, applied electrical fields have the advantage of heating soils internally, where the soil acts as the heat source. Thus, low permeability zones or complex, heterogeneous soils can be treated. Electrical heating also provides an in situ source of steam to accelerate further removal of volatile organics from soils. This enables higher molecular weight compounds that are not very volatile to be removed by simple 
venting. Removal of soil moisture (as steam) also tends to increase the air permeability of soils, which can add further to the rate of contaminant removal during venting. Effective soil heating can provide a cost effective alternative to conventional SVE or soil excavation followed by ex situ treatment.

Six-phase heating is a technique that uses common low-frequency

electricity to heat soils as an enhancement to SVE (Bergsman et al., 1993). The mechanism of heating is resistive dissipation of the electrical energy. SPSH uses conventional single-phase transformers to convert standard three-phase electricity into six-phase electricity. Electrodes are inserted into the ground in one or more circular arrays of six per array. Each electrode is connected to a separate transformer wired to provide it with a separate current phase. A seventh neutral electrode located at the center of the array doubles as an SVE vent. The six electrode array was chosen because it provides a more uniform distribution of electrical currents in the soil than other electrode array geometries.

The SPSH electrode system can be installed using common drilling equipment and constructed of well casing materials. Unlike radio frequency heating, SPSH uses conventional utility transformers, resulting in significantly lower capital cost.

\section{DEMONSTRATION OBJECTIVES}

The primary objective of the SPSH demonstration is to show the utility of 
SPSH technology as a process enhancement for SVE in clay soils. Specific test objectives for the demonstration are as follows:

1) Demonstrate that SPSH accelerates the removal of TCE and PCE from clay soils compared to conventional SVE.

2) Collect sufficient data to project economic feasibility of commercial application of SPSH technology.

3) Quantify the areal and vertical distribution of heating due to SPSH.

4) Demonstrate functional electrode and vent designs.

In addition to the SPSH objectives, Lawrence Livermore National Laboratory (LLNL) collected data during the SPSH test to produce electrical resistance tomography (ERT) images. Because temperature and water saturation each affects the soil electrical resistance, ERT records the combined effects of heating and drying. However, the two- and three-dimensional reconstruction of the subsurface should give further evidence of temperature changes and soil drying.

\section{FIELD EQUIPMENT AND OPERATION}

Field implementation of SPSH can be separated into three parts:

1) construction of surface facilities, 2) installation of sub-surface equipment, and 3) operations. Figure 1 shows the electrode array, the location of the monitoring wells, and principal surface equipment used for the SPSH demonstration. The surface equipment included a trailer-mounted, $750 \mathrm{kVA}$ power plant that supplied 
$480 \mathrm{~V}$, three-phase power to a six-phase power transformer. The six-phase transformer was specially designed for use in soil heating applications and is rated at $950 \mathrm{kVA}$. A remote computer controlled the output voltages for each electrode. The power transformer used multiple link-tap changes to attain discrete voltages between 300 and 2400 V [line-to-neutral (1-n)]; Silicon Control Rectifiers allow further adjustment of voltages. The electrodes, which were positioned $60^{\circ}$ apart on a $\mathbf{3 0} \mathrm{ft}$ diameter circle, were connected to the transformer via insulated power cables lying on the soil surface. The soil surrounding each electrode was supplied with water through a drip system to the electrified regions that spanned the clay zone. A vacuum system pulled air and contaminant vapors from the soil and through a condenser to removed the steam generated by heating. Water that collected in the vent well was removed by a air-actuated piston pump with remote speed control (Hydrostar 8001, Instrumentation Northwest).

Figure 2 gives a simple schematic of the depth from surface of two typical electrodes, the central vent, and the monitoring wells (Figure 2 does not show the areal position of these wells). The depths of the targeted clay zone and thermocouples are also shown. For each monitoring well, the placement of the thermocouples was chosen to give measurements in the sand above and below the clay, two measurements within the clay, and one measurement in the sand adjacent to the clay. Sandpacks around slotted pipes were used for pressure communication with the soil, and Figure 2 shows the location of these sandpacks. Pressure transducers located at the surface measured the pressure at these 
locations.

An extensive program of subsurface monitoring was designed to quantify removal of PCE and TCE from the soil and the extent of soil drying. Soil samples were taken, essentially every foot, from six wells prior to heating and adjacent to these wells after heating; analysis of these samples is ongoing. The difference between the pre- and post-test samples will give critical information for assessing the efficacy of SPSH.

The demonstration consisted of the three phases: 1) baseline SVE test without heating; 2) SPSH with venting; and 3) venting after heating. The baseline venting spanned 12 days, and the heating covered 25 days. Figure 3 shows the power applied to the six electrodes during the heating phase. Electrical heating began on 11/3/93 with a few days of system testing at lower power levels. Between $11 / 7 / 93$ and $12 / 2 / 93$ an average power of $200 \mathrm{~kW}$ was applied to the electrode array. Figure 4 shows the mean voltage $(1-n)$ applied to the electrodes. Between $11 / 7 / 93$ and $12 / 2 / 93$, the mean voltage was about $1000 \mathrm{~V}$. The transformer and surface equipment were automated, and the SPSH system operated unattended beginning $11 / 19 / 93$. Toward the end of the heating, the soil resistivity increased so the voltage was increased to $2400 \mathrm{~V}(1-n)$ to maintain power input levels. Periods when the mean voltage is zero represent periods of power shutdown for maintenance and data gathering (i.e., LLNL conducted measurements for ERT, collection of soil gas samples, etc.). 


\section{RESULTS AND DISCUSSION}

Heating

Quantifying the areal and vertical soil heating was a main objective of this demonstration. As shown in Figure 2, thermocouples were placed at five depths in six different wells. Figures 5 through 10 show the temperatures measured by these thermocouples. An important attribute of electrical resistive heating is its ability to heat lower permeability soils. The clay zone temperatures are represented by the thermocouples at depths of $34 \mathrm{ft}$ and $36 \mathrm{ft}$, and the sand above and below the clay, by the thermocouples at $27 \mathrm{ft}$ and $43 \mathrm{ft}$, respectively. In Figures 5 through 9, the clay-zone temperature increases much faster than the sand zones, confirming the preferential heating of the clay. The difference in heating results from the clay being more electrically conductive than the sand.

The temperature in the clay zone rose to $100^{\circ} \mathrm{C}$ (PT-1 and PT-2 peaked at $105^{\circ}$ to $110^{\circ} \mathrm{C}$ ) after 8 days of heating. Most of the data show the sand above and below the clay also rising to essentially $100^{\circ} \mathrm{C}$ after 10 to 15 days of electrical heating. Electrical heating continued after reaching $100^{\circ} \mathrm{C}$ to boil the moisture within the soil. Figure 10 gives the soil temperature at OW3, which is located $8 \mathrm{ft}$ outside the $15 \mathrm{ft}$ radius electrode array. At this location, the soil heats more slowly than within the electrode array because most of the electrical energy is delivered close to or within the array.

Figure 11 shows the areal uniformity of the temperature during SPSH. The 
temperatures are for thermocouples within the clay zone in the central vent, OW1, OW2, and OW3. The temperature at the central vent is slightly less because the vacuum applied to this vent lowered the vapor pressure (boiling point) of water at this location.

\section{Effect of Heating on Soil Properties}

One objective of electrical soil heating is increasing the air permeability of the soil by drying the soil. Figure 12 shows the cumulative water removed from the central vent as condensed steam. Substantial water removal did not occur until the soil reached essentially $100^{\circ} \mathrm{C}$. At the end of electrical heating, 16,000 gal of water had been removed through the vent. Because the soil was hot at the end of electrical heating, venting continued without heating into January 1994, excluding a 2-week break for drilling in December. At the end of venting, 17,000 gal of condensate had been removed. For comparison, the electrode drip system, which operated essentially continuously during the heating phase of the demonstration, added about 5,500 gal of water with an average salt concentration of $500 \mathrm{mg} / \mathrm{l}$ to the soil. A total of $24 \mathrm{lb}$ of table salt was injected.

Soil heating also affects the electrical resistance of the soil. Initially, the resistance decreases with increasing soil temperature. However, as the soil dries, the resistance increases. Figure 13 shows the results for the mean resistance of the six electrical phases. Between $11 / 7 / 93$ and $11 / 14 / 93$, the resistance decreased smoothly; during this period, the soil temperature rose to $100^{\circ} \mathrm{C}$. Between 
$11 / 15 / 93$ and $11 / 24 / 93$, the resistance went through a series of slow increases and drops. The increases are likely due to soil drying near the electrodes. The drops resulted from process changes that included adjustments of the water addition rate and voltage at individual electrodes. After 11/24/93, the resistance increased steadily. The electrode drip system was stopped on $11 / 29 / 93$, but the power level was maintained, causing a rapid increase in resistance due to soil drying near the electrodes.

\section{Contaminant Removal}

The ability of temperature increases to accelerate remediation varies depending on the mechanism limiting the rate of contaminant mass transfer within the soil. At the Savannah River Site, the thick clay zone sets the stage for tremendous mass transfer resistances. The mass transfer resistance is only from the clay, not the inter-layering. Before heating, remediation of the clay is expected to be limited by diffusion of contaminant through water within the clay to the more permeable sand layers where the contaminant can be swept away. After heating and partial drying, steam will occupy a portion of the clay pore space. At this point, contaminants may transfer from the water into this steam and move within the gas phase to the permeable sand layer. Contaminant movement within the gas space may still be diffusion limited, or if sufficient water volatilization occurs, convection of contaminant by in situ steaming will occur. In the case where mass transfer limitations are insignificant, heating the soil raises the concentration of the 
contaminant in air passing through the soil.

A variety of data can be used to quantify accelerated removal of contaminants from the soil due to heating. Soil samples have been taken from observation wells inside (hot) and outside (warm) the electrode pattern. Comparison in the contaminant removal from these wells will show the effect of heating on remediation: It was also expected that contaminant concentration in the air drawn from the central vent would respond to changes in soil temperature. Figure 14 shows the PCE and TCE concentration in the off gas. Also shown is an extrapolation of the PCE baseline data without heating. The difference between the baseline extrapolation and the off-gas concentration during heating indicates the degree of acceleration; the data in Figure 14 show little acceleration. However, a number of observations make these data difficult to interpret. In particular, it appears that a more highly contaminated region within the influence of the vent but outside the heated zone greatly affected the off-gas concentrations. This interpretation explains the observation of the contaminant concentration in the vent gas being initially low, then increasing 12 hours after initiating venting. Soil gas samples from PT-1 and PT-2 confirm the initial low concentrations and the rise in concentration after venting. The 12 hour delay for the higher concentration gas to arrive suggests that this region is outside the heated zone, based on modeling results. Accordingly, even moderate changes due to heating may have been masked. Post-test soil sampling will be the most valuable tool for assessing removal of contaminants for the clay. Initial comparison of contamination levels in 
pre- and post-test soil samples shows substantial soil remediation; analysis of these data is ongoing.

\section{SPSH Energy Usage}

By using the thermocouple data on vertical and areal heating, it is estimated that approximately $1100 \mathrm{~m}^{3}$ of soil was heated to above $70^{\circ} \mathrm{C}$. This rough estimate should be improved by combining the thermocouple data with a computer model of electrical heating of the subsurface. Figure 15 shows the energy applied to the soil; at the end of the test, $100,000 \mathrm{kWh}$ of energy had been applied to the soil. Combining this energy usage with the rough estimate of the heated volume gives an energy usage of $90 \mathrm{kWh} / \mathrm{m}^{3}$, or $\$ 7 / \mathrm{m}^{3}$ at $\$ 0.07 / \mathrm{kWh}$. As with most heating methods, the energy cost to heat the soil is small when compared to the costs for the capital equipment for the electrical system, the off-gas destruction system, and the operator time.

\section{CONCLUSIONS}

1) SPSH heated the Savannah River Site soils to about $100^{\circ} \mathrm{C}$ within 8 days and maintained this elevated temperature as the soil was dried.

2) Electrical resistive heating (SPSH) effectively heated the low permeability clay zone.

3) 17,000 gal of condensed steam was removed from the central vent, 
indicating substantial drying of the soil. $5,500 \mathrm{gal}$ of water with $500 \mathrm{mg} / \mathrm{l}$ of table salt were added at the electrodes.

4) Off-gas concentrations showed little change during heating, most likely due to a more highly contaminated region within the influence of the vent but outside the heated zone. Initial comparison of contamination levels in preand post-test soil samples shows substantial soil remediation; analysis of these data is ongoing.

\section{ACKNOWLEDGMENTS}

Design of the SPSH systems for this demonstration was performed by T. M. Bergsman, P. A. Gauglitz, E. N. Greenwell, W. O. Heath, M. C. Miller, R. W. Moss, R. L. Richardson, R. Schalla, and J. S. Roberts; D. W. Glover assisted in field installation of equipment; and L. M. Peurrung and S. M. Caley were shift operators during the demonstration. These staff are all from the Pacific Northwest Laboratory (PNL). The project was managed by M. H. Schlender, also from PNL. T. R. Jarosch, C. A. Eddy-Dilek, and B. B. Looney of WSRC provided drilling, soil sampling, construction, off-gas treatment, and contaminant analyses. In particular, for on-site support we thank Shirley Burdick, Snuffy Clark, Ken Lombard, and Randy Raymond of Bechtel Savannah River, and Marlesia Keenan, Dee Dee Stewart, and Johnny Simmons of WSRC. This work was sponsored by the DOE Office of Technology Development as part of the VOC Non-Arid ID. 


\section{REFERENCES}

Bergsman, T. M., J. S. Roberts, D. L. Lessor, and W. O. Heath. 1993. "Field Test of Six-Phase Soil Heating and Evaluation of Engineering Design Code." Presented at the Waste Management Symposia '93, Tucson, Arizona.

EPA. 1991. Guide for Conducting Treatability Studies Under CERCLA: Soil Vapor Extraction - Interim Guidance. U.S. Environmental Protection Agency.

Eddy, C. A., B. B. Looney, J. M. Dougherty, T. C. Hazen, and D. S. Kaback. 1991. Characterization of the Geology, Geochemistry, Hydrology, and Microbiology of the In Situ Air Stripping Demonstration Site at the Savannah River Site (U). WSRC-RD-91-21, Westinghouse Savannah River Company, Aiken, South Carolina.

Eddy-Dilek, C. A., B. B. Looney, T. C. Hazen, R. L. Nichols, C. B. Fliermans, W. H. Parker, J. M. Dougherty, D. S. Kaback, and J. L. Simmons. 1993. Post-Test Evaluation of the Geology, Geochemistry, Hydrology, Microbiology, and Hydrology of the In Situ Air Stripping Demonstration Site at the Savannah River Site (U). WSRC-TR-369, Westinghouse Savannah River Company, Aiken, South Carolina.

Looney, B. B., T. C. Hazen, D. S. Kaback, and C. A. Eddy. t 1991a. Full Scale 
Field Test of the In Situ Air Stripping Process at the Savannah River Integrated Demonstration Test Site (U). WSRC-RD-91-22, Westinghouse Savannah River Company, Aiken South Carolina.

Looney, B. B., J. B. Pickett, and J. J. Malot. 1991b. Pilot Test of a Vacuum Extraction System for Environmental Remediation of Chlorinated Solvents at the Savannah River Site (U). WSRC-RD-91-19, Westinghouse Savannah River Company, Aiken, South Carolina.

Pedersen, T. A. and J. T. Curtis. 1991. Soil Vapor Extraction Technology Reference Handbook. EPA/540/2-91/003, U. S. Environmental Protection Agency, Washington, D.C. 
FIGURE 1. Surface Equipment for Six-Phase Heating lelectrode array and other wells drawn to scale, other equipment not drawn to scale)

FIGURE 2. Depth from surface of the Clay Zone, Electrodes, Thermocouples, and Pressure Measurements. The clay zone interval is shown only for the wells that were cored and logged; the clay is continuous throughout the test area.

FIGURE 3. Power applied to SPSH Array

FIGURE 4. Mean Voltage Applied to SPSH Electrodes

FIGURE 5. Temperature at Well MHV40 (PT-1)

FIGURE 6. Temperature at Well MHV41 (PT-2)

FIGURE 7. Temperature at Well MHV30 (Central Vent)

FIGURE 8. Temperature at Well MHV37 (OW1)

FIGURE 9. Temperature at Well MHV38 (OW2) 
FIGURE 10. Temperature at Well MHV39 (OW3)

FIGURE 11. Temperature in Clay Zone (34 ft and $36 \mathrm{ft}$ ) as a Function of Areal Position (SPSH Gives Uniform Heating Within Electrode Array)

FIGURE 12. Condensed Steam Removed from the Vacuum Extraction Vent During Heating

FIGURE 13. Average Phase Resistance

FIGURE 14. Contaminant Concentration in Vent Gas at Orifice Meter

FIGURE 15. Energy Applied to Soil 


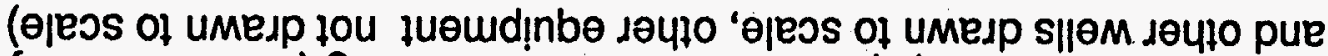

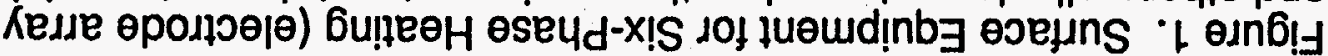

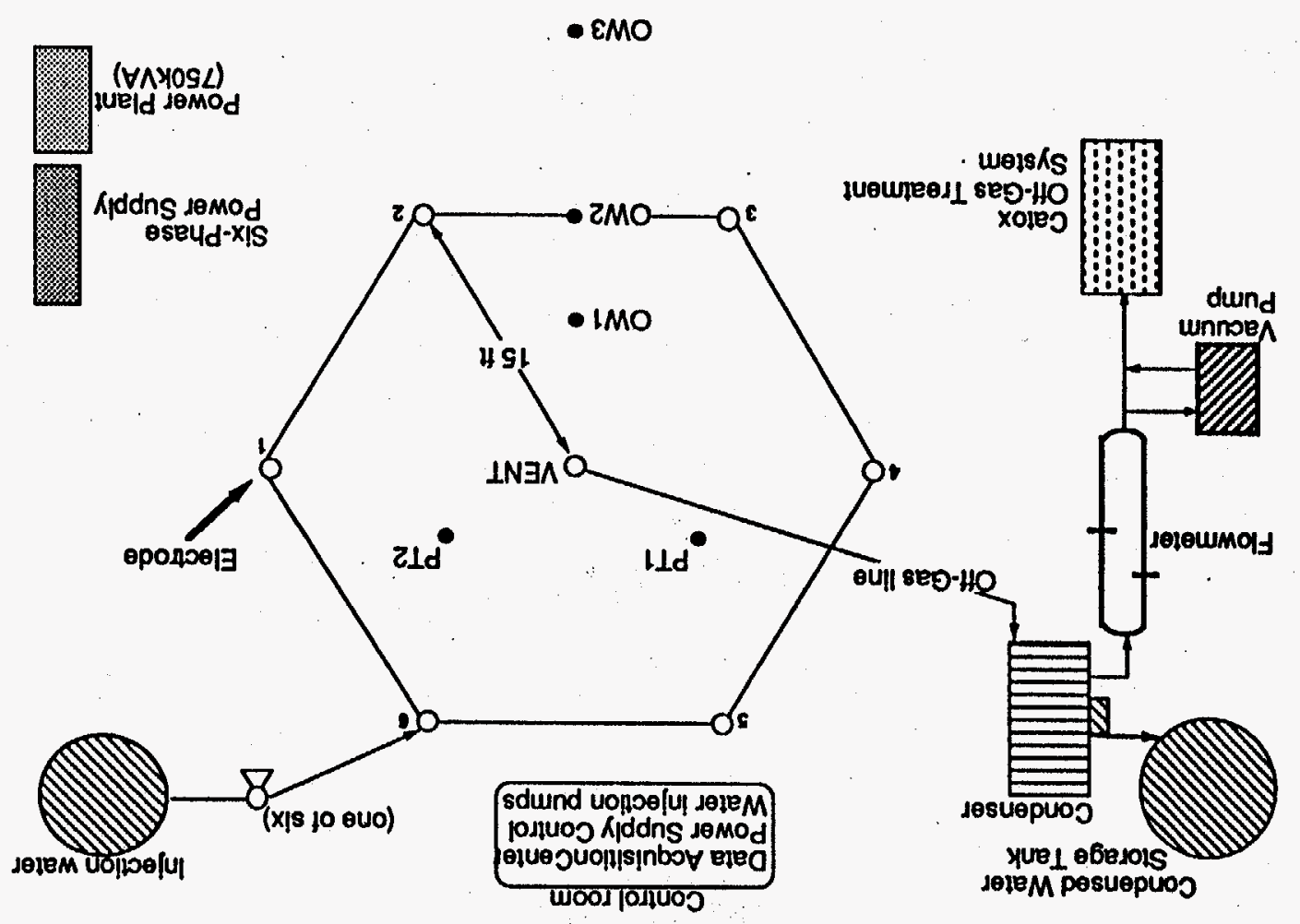




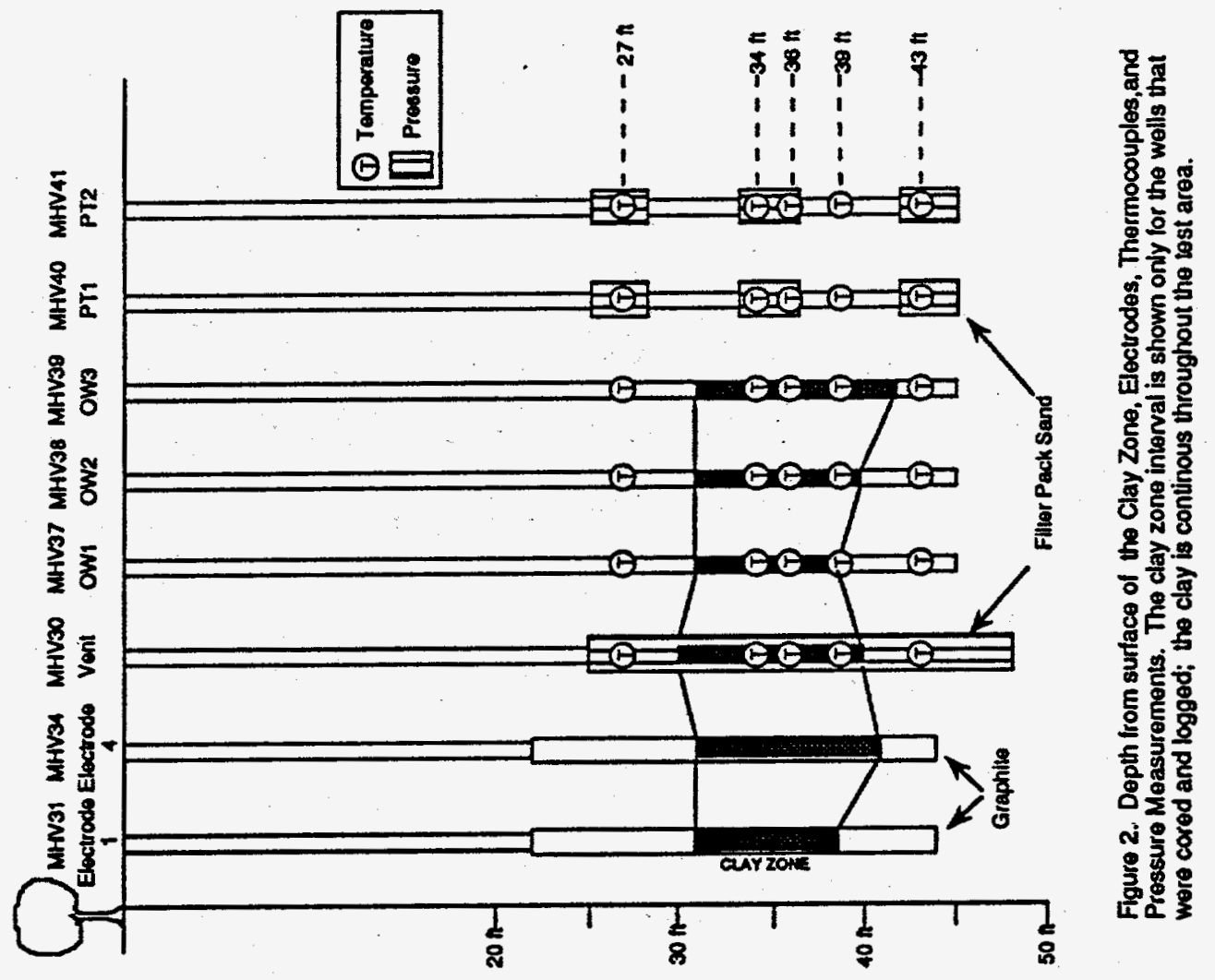




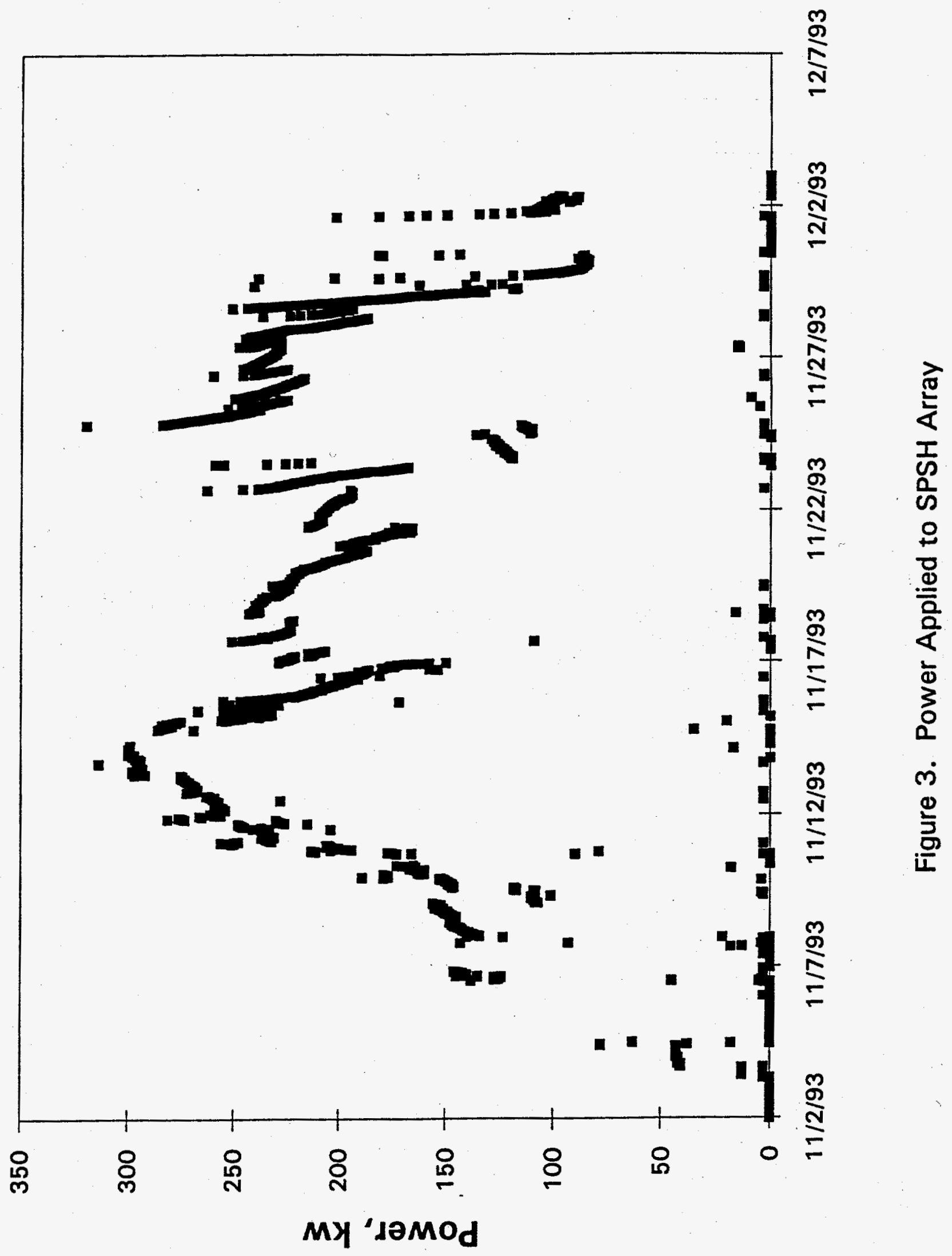




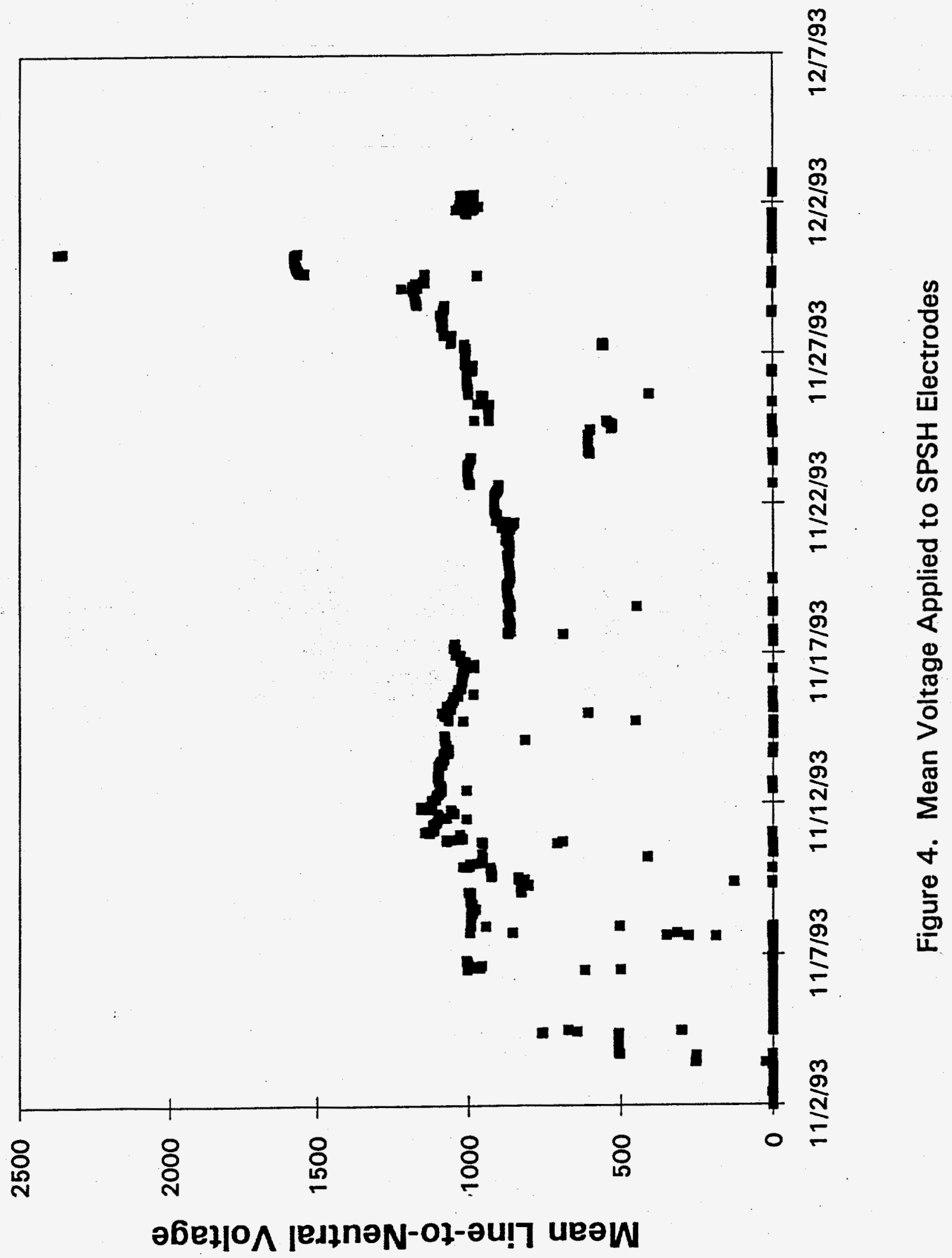




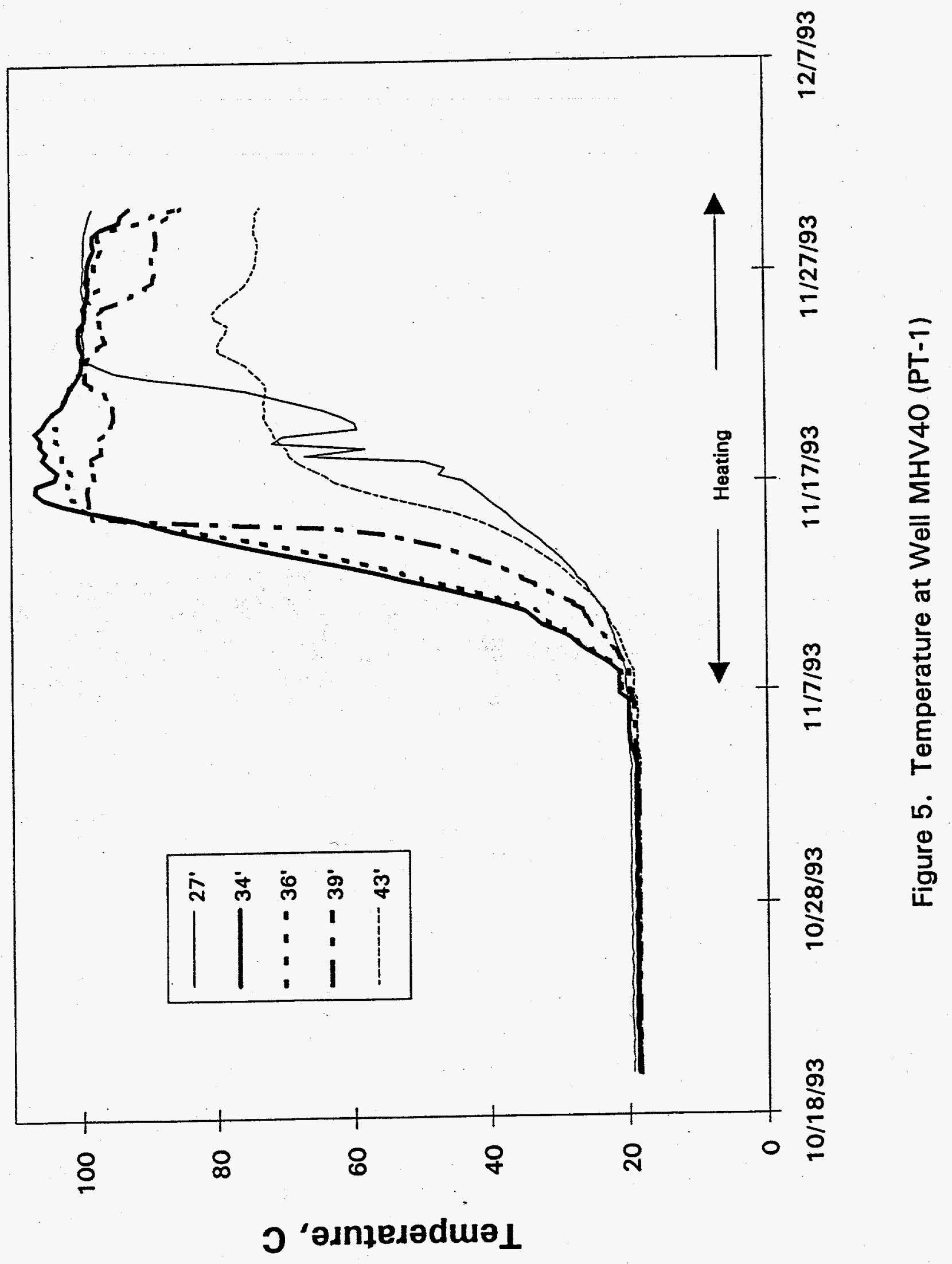




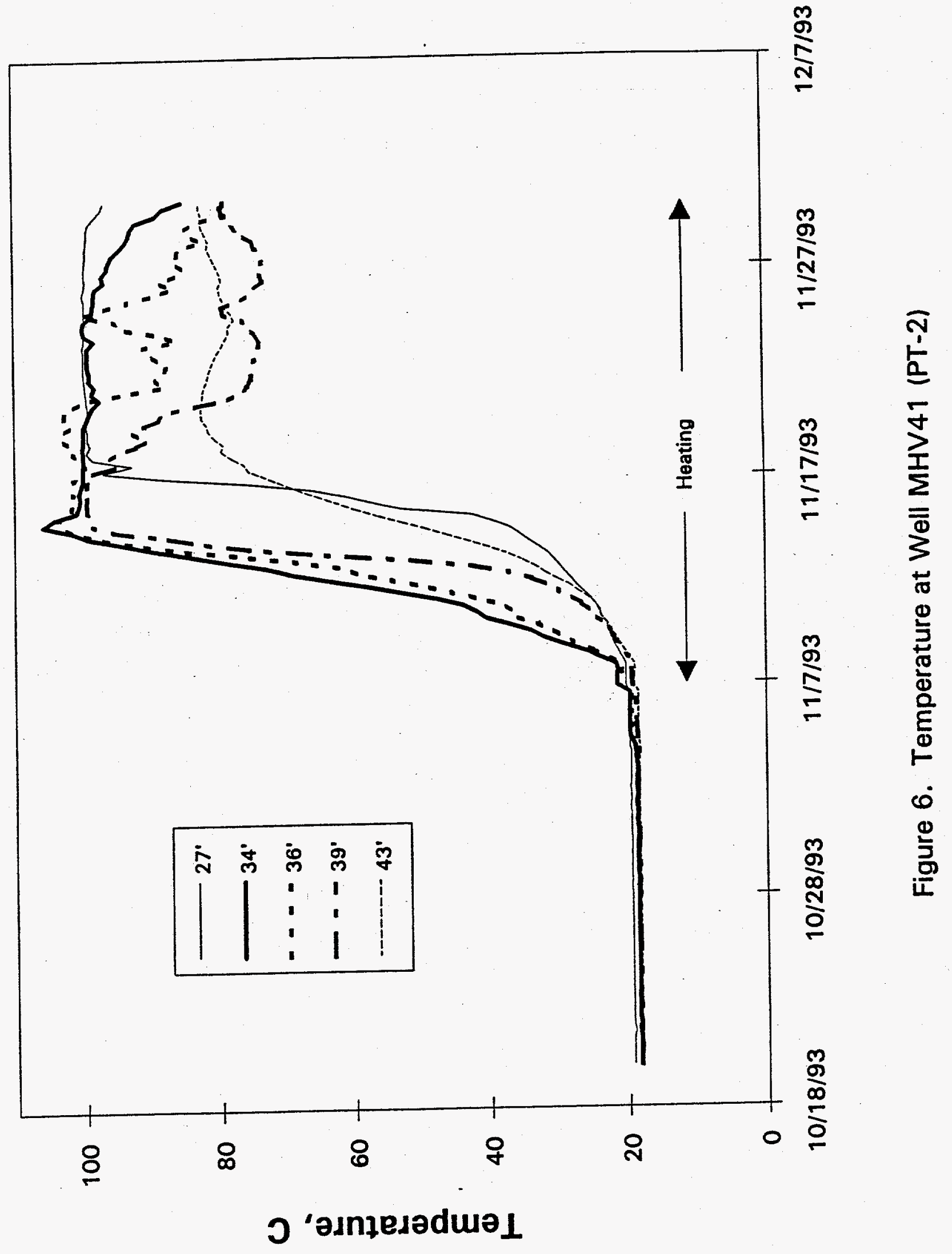




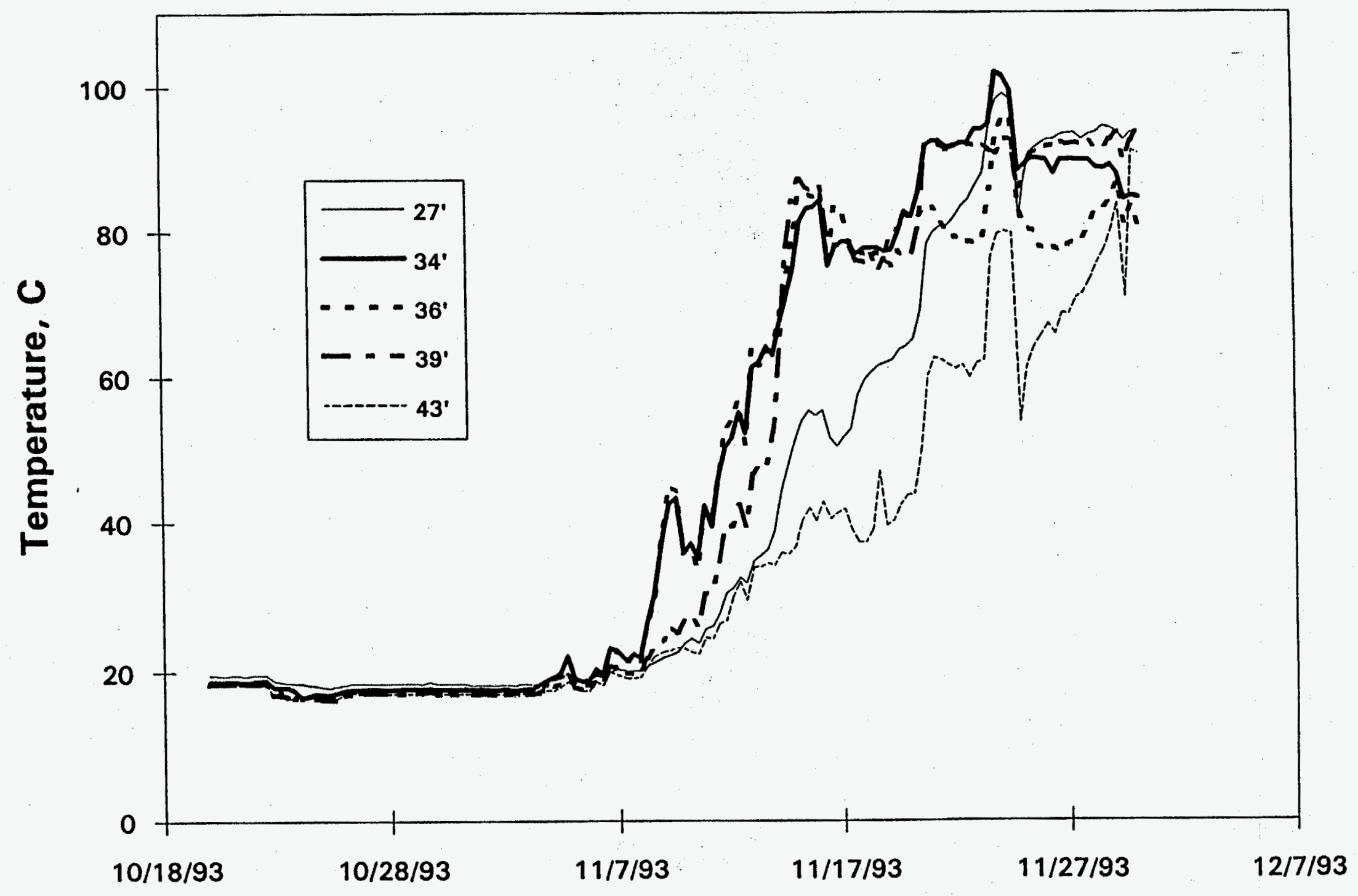

Figure 7. Temperature at Well MHV30 (Central Vent) 


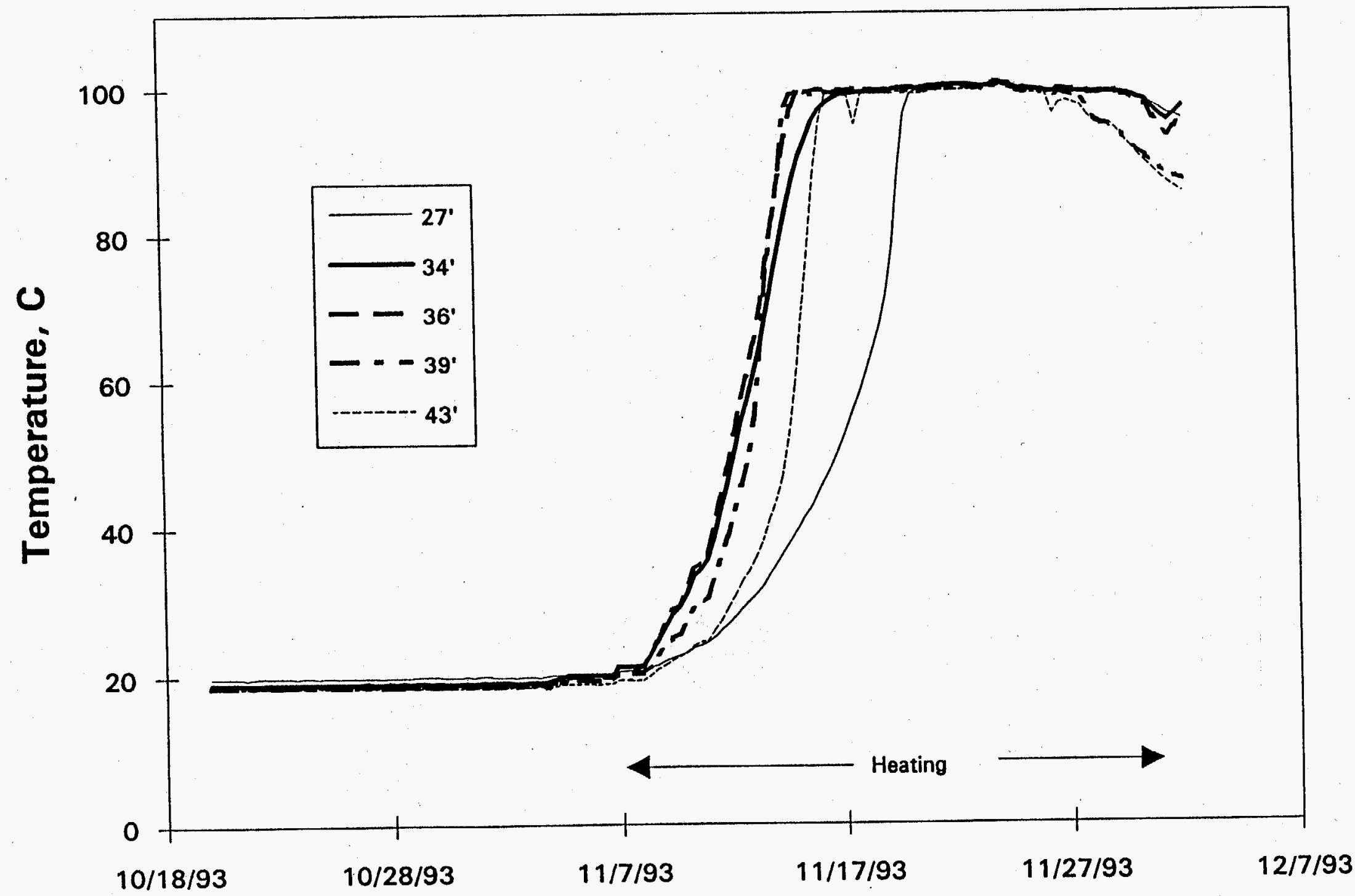

Figure 8. Temperature at Well MHV37 (OW1) 


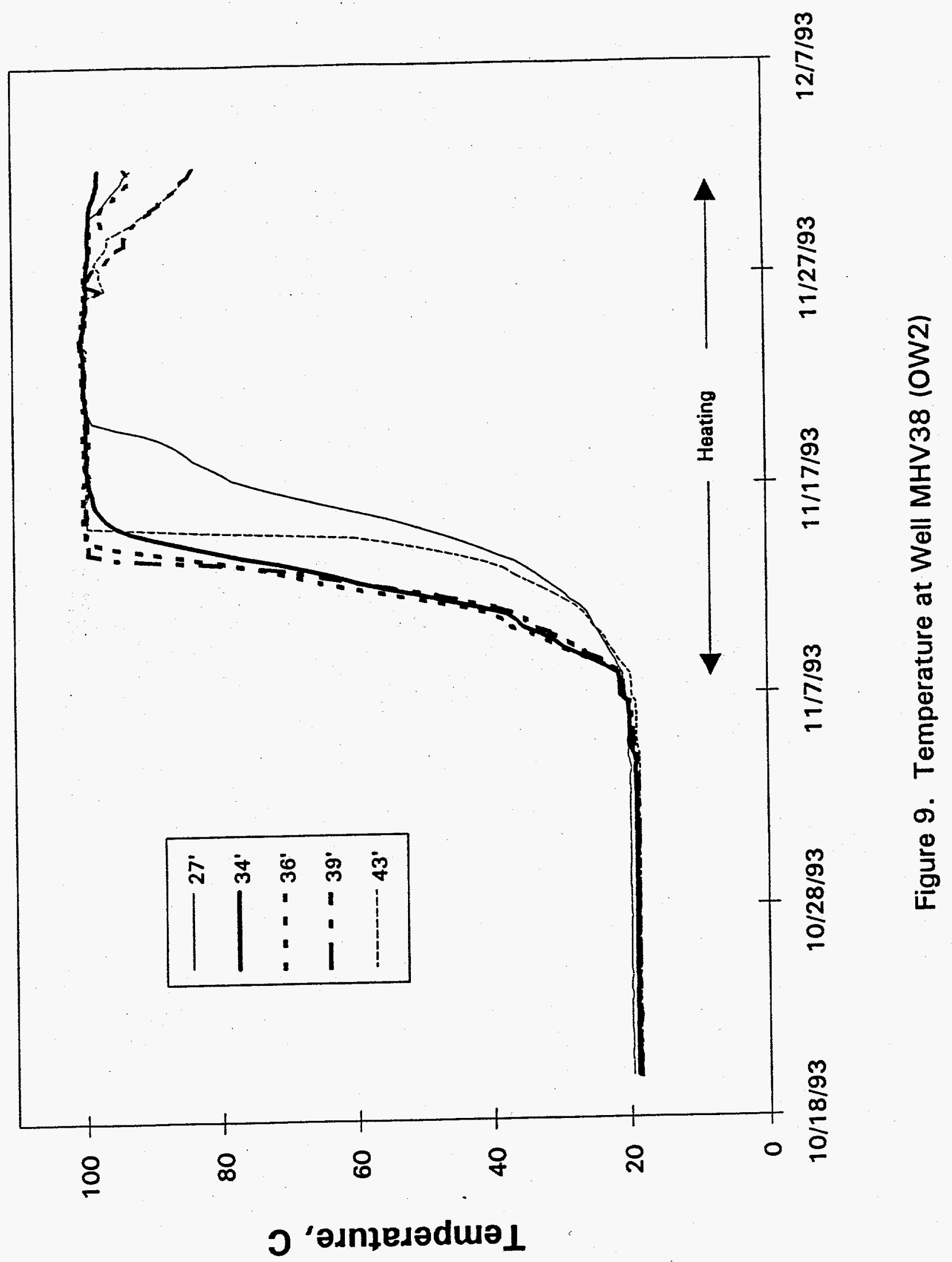




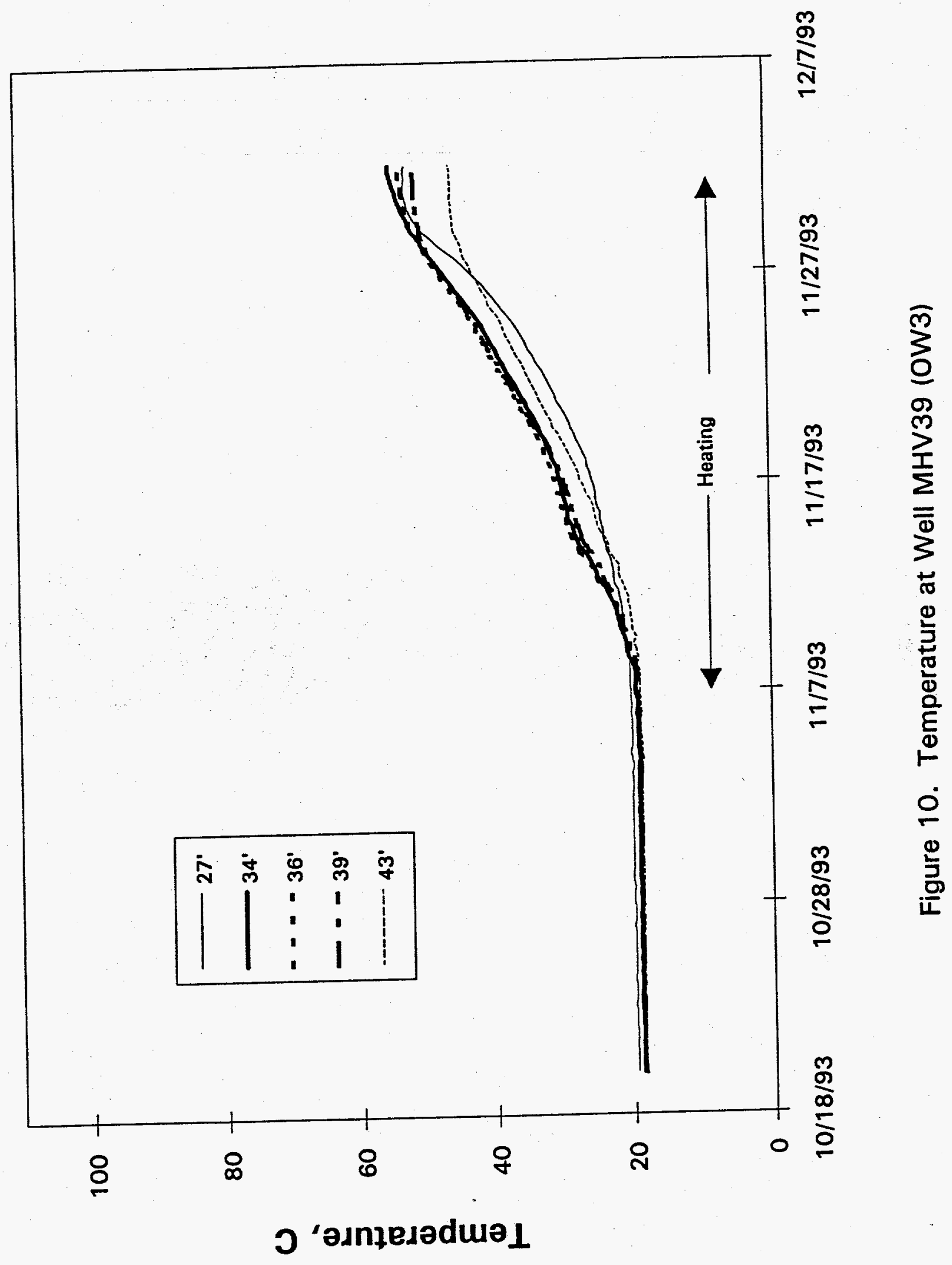




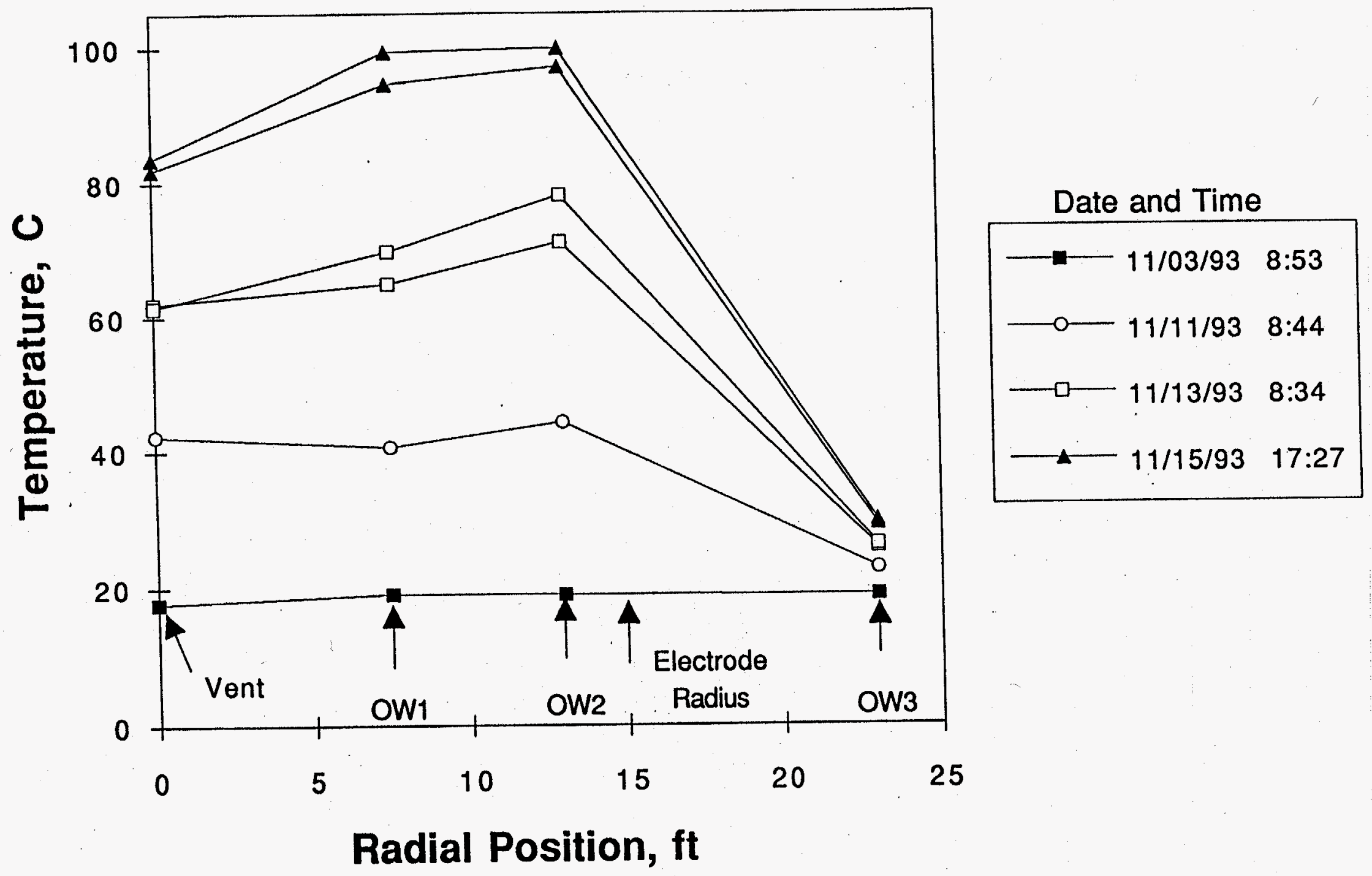

Figure 11. Temperature in Clay Zone (34 ft and $36 \mathrm{ft}$ ) as a Function of Areal Position (SPSH Gives Uniform Heating Within Electrode Array) 


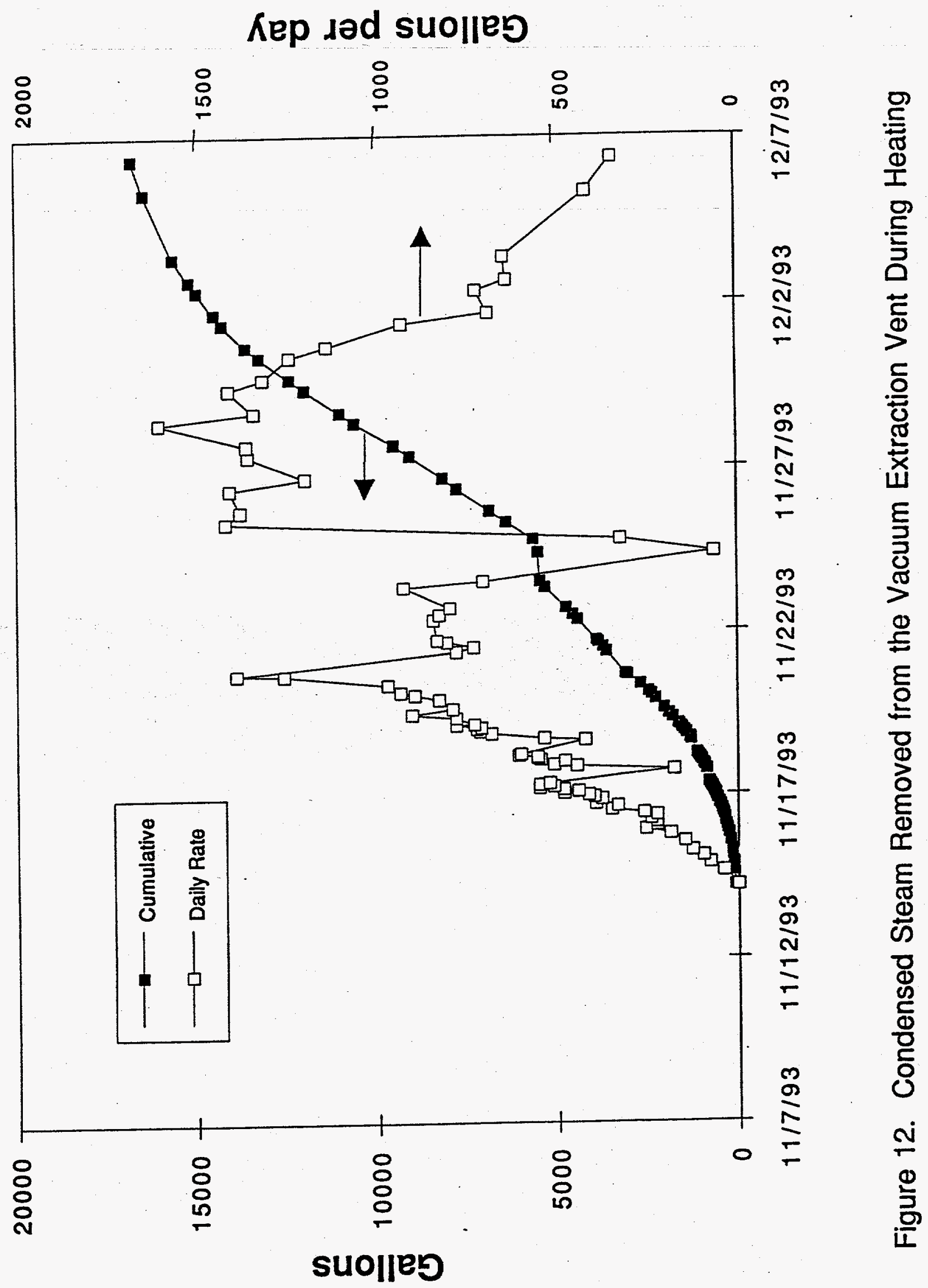




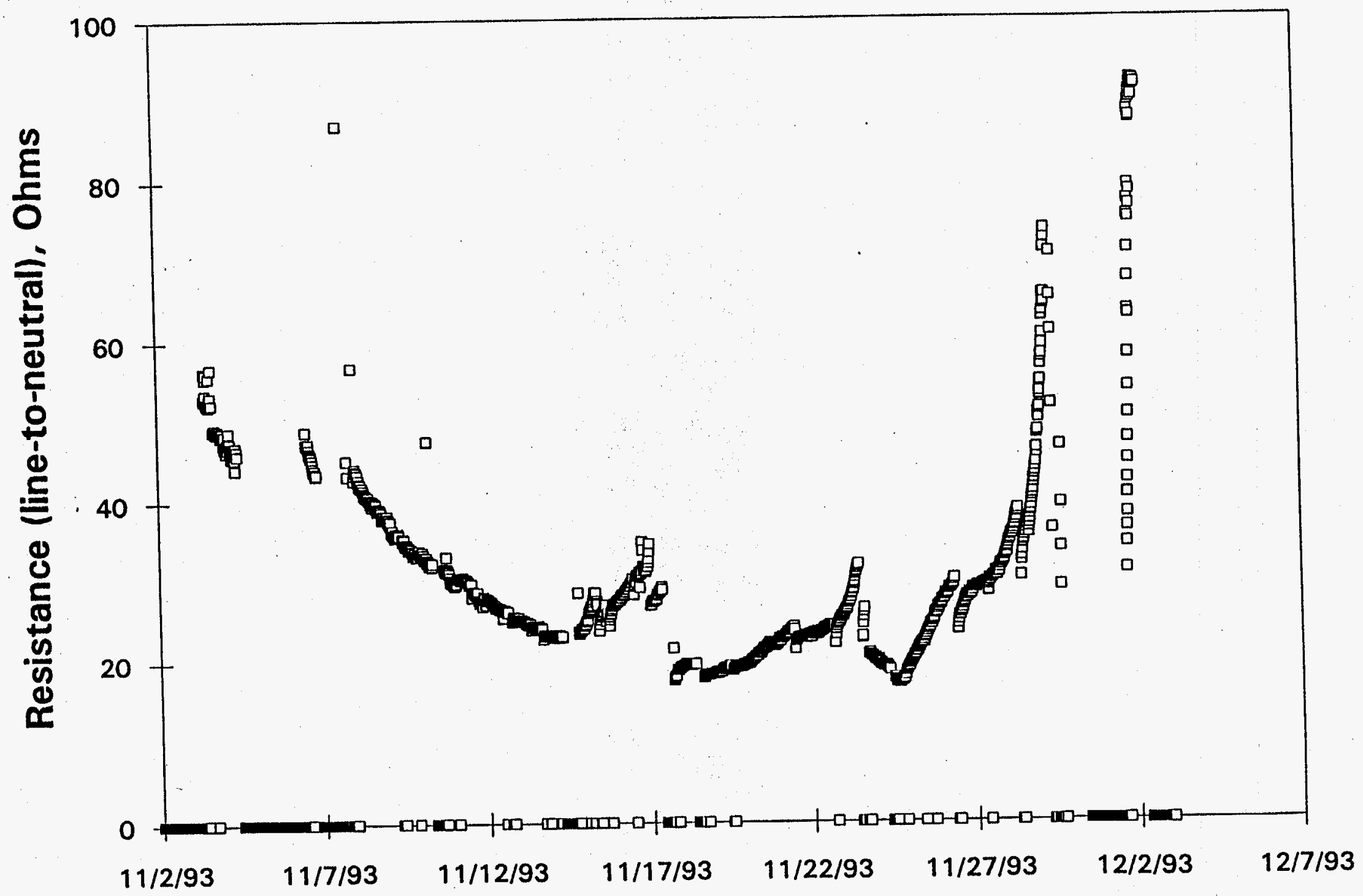

Figure 13. Average Phase Resistance 


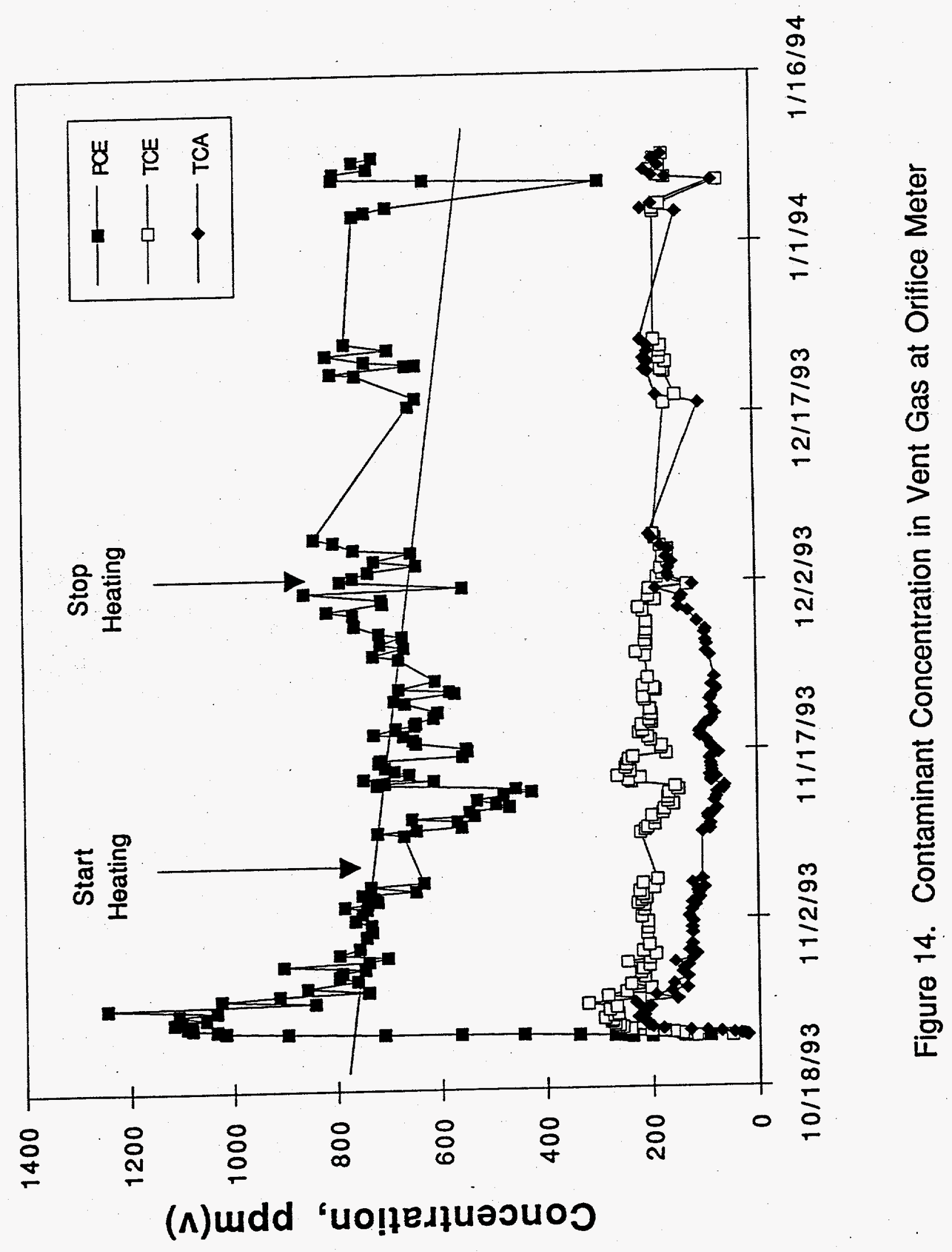




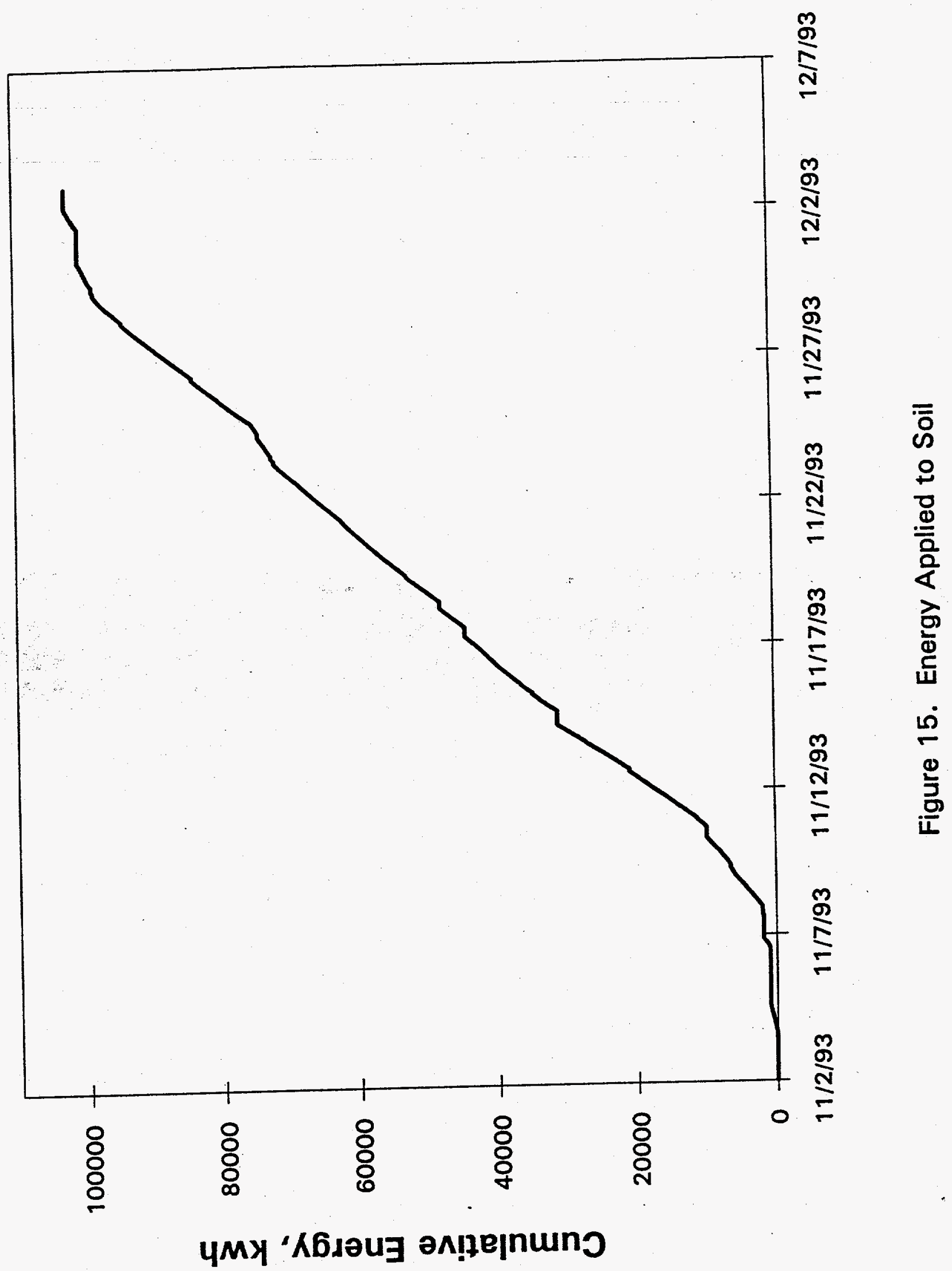

